\title{
Assessment Strategies for Enhancing Students' Mathematical Problem-solving Skills: A Review of Literature
}

\author{
Fidele Ukobizaba ${ }^{1 *}$, Gabriel Nizeyimana ${ }^{1}$, Angel Mukuka ${ }^{1,2}$ \\ ${ }_{1}^{1}$ African Center of Excellence for Innovative Teaching and Learning Mathematics and Science (ACEITLMS), University of Rwanda \\ College of Education (URCE), RWANDA \\ 2 Department of Mathematics, Science, and Technology Education, Mukuba University, Kitwe, ZAMBIA
}

Received 2 October 2020 - Accepted 9 January 2021

\begin{abstract}
Students' ability to apply mathematical knowledge to various situations has been one of the major concerns in mathematics education research. However, little is known about the assessment strategies that have a substantial contribution to the development of mathematical problemsolving skills in kindergarten children through to upper secondary school students. In this review of existing literature, we discuss the contribution of assessment strategies in the last three decades in strengthening learners' acquisition of mathematical problem-solving skills. Twenty peerreviewed conference papers and journal articles published from 1997 to 2020, downloaded from Google Scholar, Academia, and ERIC databases have been analyzed and discussed. Based on this review, it has been noted that the application of assessment strategies such as Structure of the Observed Learning Outcomes taxonomy, Higher-Order Thinking Skills model, performance assessments, authentic assessments, dynamic assessments, and video games-based assessments alongside the learner-centered/active learning methods like problem-based and cooperative learning is bound to strengthen students' mathematical problem-solving skills.
\end{abstract}

Keywords: assessment strategies, mathematical problem-solving skills, 21st century skills

\section{INTRODUCTION}

Following the movement of problem-solving in the United States of America (USA) as it expanded worldwide in the 1980s, problem-solving became the central focus in education (Fan \& Zhu, 2007; Rosli et al., 2013). According to Novita et al. (2012), mathematical problem-solving refers to "mathematical tasks that have the potential to provide intellectual challenges for enhancing learners' mathematical understanding and development" (p. 133). Since one of the objectives of mathematics education is to prepare learners for the workplace (Gravemeijer et al., 2017), the introduction of a competence-based curriculum in the Rwandan education system was meant to address this educational reform (Rwanda Education Board [REB], 2015). Learning to solve problems is the primary reason for studying mathematics (Galovich \& Schoenfeld, 1989; Novita et al., 2012). Likewise, mathematics does not only play a vital role in preparing learners for further education and future career development but also strengthens students' ability to solve real-world problems (Pandey, 1991).

Though learners need skills such as critical thinking, effective communication, innovation, and the ability to solve problems collaboratively, existing pedagogical practices do not seem to have dealt with these aspects adequately (Scott, 2015). Moreover, the gap between science, technology, engineering, and mathematics (STEM) education as well as the required workplace skills in the industry, academia, and the government is still quite appalling (Jang, 2016; Sluijsmans et al., 1998). Hence, there is a need for understanding the kind of mathematical skills needed in today's world and the shifts that should be made in both content and pedagogy for preparing students to acquire relevant $21^{\text {st-century }}$ skills including mathematical reasoning, critical thinking, and mathematical problem-solving (Gravemeijer et al., 2017; Jang, 2016; Turiman et al., 2012). These skills can be developed by employing teaching strategies that actively involve students in the 


\section{Contribution to the literature}

- The study reviewed, discussed, and presented different assessment strategies employed in enhancing students' mathematical problem-solving skills over the last three decades.

- The study highlights the extent to which these assessment practices have contributed to the strengthening of students' mathematical problem-solving skills attainment.

- The study informs teachers and education policymakers on assessment strategies that are bound to improve mathematical problem-solving skills.

learning process and using a kind of assessment that involves students' intellectual challenges rather than memory retrieving (Ebiendele, 2012). This could be attributed to the fact that assessment drives students' learning (Kanjee, 2009), and plays a great role in the implementation of the curriculum in which students are expected to acquire different skills and competencies (Drijvers et al., 2019).

Some scholars believe that mathematics teachers should show students how to solve problems (Lester, 2013), others think that it is better when students themselves manage to find out how to solve problems (Schoen et al., 2019), while others have argued that students can solve the real-world problem after memorizing mathematical facts (Ebiendele, 2012; Wolf et al., 1991). Nevertheless, Stacey (2005) argues that "problem-solving is a teaching method, rather than being a goal in itself" (p.342). Since the idea of problemsolving is conceived at a very early age, prekindergarten, kindergarten, and primary children can discover problems while playing (Charlesworth \& Leali, 2012; Kelly, 2006). In that regard, this review focuses on assessment strategies used for assessing mathematical problem-solving skills from kindergarten through to upper secondary levels of education.

The study conducted by Nizeyimana and Muthukrishna (2003) revealed that teachers employ unsound practices while implementing the curriculum. By focusing on increasing the number of students who may pass the national examinations, some teachers spend much of their time on past paper examination explorations. This is why there is a need to orient both pre-service and in-service teachers on appropriate instructional and assessment approaches that support the development of students' mathematical problemsolving skills. Similarly, integrating an authentic assessment with teaching strategies that ensure that students have got learning opportunities that can enable them to seek solutions consistently (Hopkins, 2000), is very critical. Effective use of assessment towards mathematical problem-solving can have a positive impact on education and society through the advancement and measurement of competencies that are needed to create productive workers and citizens (Griffin et al., 2012). Within the current economy's standards and requirements, we need to develop students' full potentials (Griffin et al., 2012; Noreen,
1993), whereby teachers teach and assess students' mathematical knowledge in a way that allows them to perform what they undoubtedly understand (Kelly, 2006). Since assessment is a critical and important educational component in supporting learning and qualification (Moss, 2013; Taras, 2008), it is important to point out that "assessment tasks should be constructed to measure the particular aspects of mathematical competencies to align assessment with curriculum" (Pettersen, 2017, p. 1). Hence, there is a call for national reform by changing how students are being assessed in mathematics (Berenson \& Carter, 1995).

\section{PURPOSE AND RESEARCH QUESTIONS}

This paper aims at reviewing different assessment practices that have been found to enhance learners' mathematical problem-solving skills attainment within the last three decades. It is also designed for deepening mathematics teachers' knowledge and understanding of assessment practices that are bound to enhance learners' critical thinking ability in solving complex problems encountered in daily life, especially at the workplace. Hence, this study intended to provide answers to the following research questions:

i. What are the assessment strategies that have been used to assess learners' mathematical problemsolving skills from1997 to 2020 ?

ii. To what extent have these assessment practices contributed to the strengthening of learners' mathematical problem-solving skills attainment?

It was anticipated that answers to the above-stated questions could provide insights into the assessment strategies that can foster learners' mathematical problem-solving skills attainment and thus, draw implications for future mathematics teaching practices.

\section{METHODOLOGY}

In this study, a desk review method was adopted. We conducted a literature search to collect data related to the contribution of various assessments as applied in teaching and learning to enhance students' mathematical problem-solving skills. At this stage of the research, peer-reviewed books, conference papers, and journal articles from Google Scholar, Academia, and ERIC databases were downloaded. These sources were deemed valid, relevant, and reliable based on their high 
academic quality. By using 'assessment strategies, types/forms of assessments, mathematical problemsolving skills for $21^{\text {st }}$ century, types of assessments for mathematical problem-solving skills, and effect/role of assessments on students' mathematical problem-solving skills' as keywords, 63 studies were obtained. With a deep analysis of the collected data, 32 studies were related to teaching strategies in enhancing problemsolving skills, and these studies were filtered out, while 31 studies that were related to assessment strategies in enhancing mathematical-problem solving skills were maintained. Since we were interested in our study's main constructs (Lavrakas, 2008), we further filtered out 11 studies from 31 studies that were concerned about assessments strategies in enhancing students' problem solving skills, and we therefore remained with 20 studies that describe the assessment strategies in enhancing students' mathematical problem-solving skills. The remaining studies were published from 1997 until 2020.

Besides the above-prescribed criteria, we only considered conference papers that appeared in accredited books of conference proceedings with ISBN. It also suffices to point out that all the papers falling out of the domain of kindergarten through to upper secondary levels of education were excluded from the analysis. Among the retained studies, 18 were journal articles and two were conference papers. The reviewed studies are presented in the table (see Appendix) displaying the authors, research title (the assessment strategies employed), research sample, and the approaches employed.

A PRISMA ${ }^{1}$ diagram was referred to, to clearly show how the acceptance and exclusion of some articles criteria (see Figure 1) was done.

\section{RESEARCH FINDINGS}

\section{Structure of the Observed Learning Outcomes (SOLO) Taxonomy}

While working with 80 Grade 11 students, using one group pretest-posttest research design, Mukuka, Balimuttajjo, and Mutarutinya (2020) found that the SOLO taxonomy is an effective tool for assessing and fostering students' mathematical problem-solving activities. Similarly, a study conducted by Lian et al. (2010) established that the SOLO taxonomy was one of the effective means of boosting students' learning outcomes in mathematical problem-solving activities.

\section{Higher-Order Thinking Skills (HOTS) Model}

Two studies fell into this category. Abdullah and Fadil (2019) used 10 Form three while investigating the emerging patterns and problems of HOTS mathematical problem-solving. They found that students who applied the HOTS model exhibited a smooth transition from a logical starting point of understanding, followed by planning, implementation, and ended with the right final answer. Equivalently, Raiyn and Tilchin (2016) investigated the impact of adaptive complex assessment (ACA), using the development of HOT skills method in a problem-based learning (PBL) environment. By calculating the coefficient of HOT development, the findings confirmed that the ACA of higher-order thinking skills led to the improvement of students' mathematical problem-solving skills.

\section{Authentic Assessments}

It has been established that authentic assessments were used in four of our reviewed studies. While Rosli et al. (2013) used authentic assessment as an assessment strategy, Darma et al. (2018) used a 2x2 factorial experimental study design. Using a performance rubric, Rosli et al. (2013) found authentic assessment to be effective in examining students' ability to solve and pose mathematical problems. Likewise, Darma et al. (2018) employed a two-way multiple analysis of variance statistical technique on a sample of 110 students. Their results showed that there was a significant difference in conceptual understanding and mathematical problemsolving between students who were taught with authentic assessment and those who were taught with the conventional assessment strategies. Besides that, Cai et al. (2013) conducted a longitudinal research project employing the Connected Mathematics Program (CMP) or non-CMP curricula in middle school. Using $11^{\text {th }}$ graders' problem-posing as the measure, a total of 390 students were involved in this study (243 former CMP and 147 former non-CMP students). These $11^{\text {th }}$ graders had all taken a baseline examination at the start of the project. Then, the students attended high schools. By using a two-way analysis of variance statistical analysis, the results showed a strong connection between the students' ability to solve a problem and their ability to pose valid problems.

Additionally, Lin (2004) designed a study to support teachers in designing problem-posing tasks to understand students' mathematical learning. The study involved seven classroom teachers who collaboratively set up a school-based team participating in an assessment project that assisted teachers in implementing assessment integral to instruction. As an assessment tool, the tasks incorporating into everyday instruction decisions about task appropriateness were often related to students' communication of their thinking, or the students' problem-solving strategies displayed in the classroom. The reviewed studies showed that through authentic assessments, students did not only develop problem-solving skills but also led

${ }^{1}$ PRISMA: Preferred Reporting Items for Systematic reviews and Meta-Analyses 


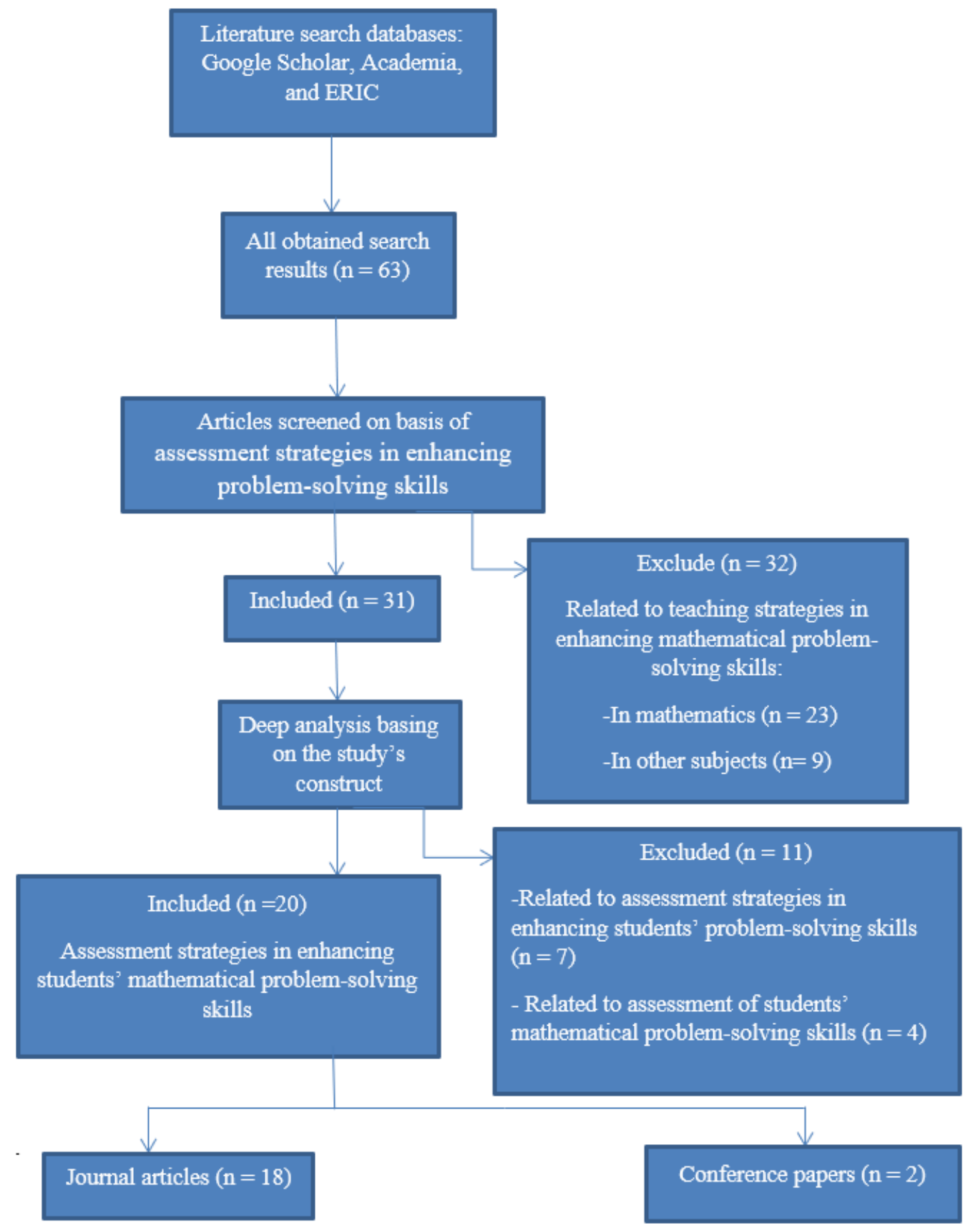

Figure 1. The PRISMA diagram of the articles' selection process of the reviewed studies

to enhanced mathematical problem-posing skills (Cai et al., 2013; Lin, 2004; Rosli et al., 2013).

\section{Performance Assessments}

It was noted that most of the reviewed studies had employed performance assessment as a tool for evaluating students' mathematical problem-solving skills. Fuchs et al. (1999) randomly selected 16 teachers and exposed them to performance-assessment (PA) driven instruction and non-PA condition. PA teachers attended a workshop, administered 3 PAs in some months. PA students showed stronger problem-solving skills in all dimensions than their counterparts who were exposed to a non-PA condition. While conducting their study, Pajares and Miller (1997) used 327 eighth-grade students, who were assessed using two forms of assessment (traditional multiple-choice vs open-ended fill-in-the-blank). The results showed that students who took the multiple-choice performance test obtained higher scores than those who took the open-ended test. Furthermore, Hasibuan and Fauzi (2020) used 32 students of Grade VIII-2 of SMP Negeri 6 Padangsidimpuan to develop the Programme for International Students Assessment (PISA) model on the content of change and relationship to measure students mathematical problem-solving ability. Data were collected using a walkthrough, documents, tests, and 
questionnaires. After the analysis of the results, it was found that the mathematical problems of the PISA model on the content of change and relationship that had been developed produced valid questions that were reliable with high interpretation, as well as practical.

After an external longitudinal study from 2013 to 2015 conducted by Frank et al. (2017), the incorporated assessment strategies were used and were composed of the task and process-level feedback on scaffolded tasks in-class, formative assignments, and the postassignment review. The analysis of students' responses from the survey, direct criterion-referenced assessment of the course outcomes all along were assessed. The findings showed that students improved in learning outcomes related to complex problem-solving throughout the course. Likewise, Novita et al. (2012) conducted a research involving four schools in Palembang. Students were given contextual problems developed by PISA, requiring them to link mathematical situational problems on the development of their problem-solving ability. The results of the study showed that the mathematical problem-solving tasks had been developed based on enhancing students' mathematical problem-solving ability. Similarly, through a quasiexperimental study, Beesley et al. (2001) used seven schools, 47 mathematics teachers, 2281 counterfactual groups, and 3896 treatment groups in the study. It was found that by using professional development for each school, and by implementing ungraded practice and student self- and peer-assessment after Assessment Work Sample Method, students were motivated to tackle complex problem-solving. Furthermore, Egodawatte (2010) has focused on how to construct an effective rubric as an assessment tool. By using an attitudinal questionnaire to the learners to rate their attitudes about self- and peer-assessment, it was reported that a welldesigned rubric is effective to self-assess and peer-assess mathematical problem-solving skills of college students.

\section{Dynamic Assessments}

Three of the reviewed studies employed dynamic assessment for assessing students' mathematical problem-solving skills. Fuchs et al. (2011) used two-stage screening for math problem-solving difficulty using dynamic assessment (DA) of algebraic learning. This research involved 122 third-grade students. In the fall, students were assessed on a test of math word-problem skill and DA of algebraic learning. In the spring, they were only assessed on word-problem performance. By using logistic regression to contrast the two models, the results showed a higher proportion of false positives, which was practically reduced when DA was included in the prediction model. Similarly, Fuchs et al. (2008) used 122 third-grade students that were assessed on language, nonverbal reasoning, attentive behavior, calculations, word-problem skill, and DA. Structural equation modeling was used for data analysis. It was inferred that contrast language, pretreatment wordproblem skill, and DA were needed to plan for learning on word-problem outcomes. Furthermore, Wang (2011) conducted a quasi-experimental study with 96 Seventh graders from three classes. All groups faced the graduated prompting assessment module of the webbased assessment test analyses, normal web-based test, and paper-and-pencil test respectively. A post-test was given to all students after the remedial teaching. It was proved that the graduated prompting assessment module of the web-based assessment test analyses, can be used for both students who need remedial teaching and those lacking different types of mathematical problem-solving knowledge.

\section{Video Games-Based Assessments}

There was only one study reviewed in this domain. Hwang et al. (2014) conducted an experimental study with 167 sixth graders. Eighty-two students in the experimental group experienced a peer assessmentbased game development approach, while 85 students that were in the control group were taught with the conventional game development approach. Basing on a post-test, the analysis of the results revealed that the peer assessment-based game development approach had the greater potential of promoting students' learning achievement, learning motivation, mathematical problem-solving skills, and the students' perceptions of integrating educational computer games.

\section{DISCUSSION AND IMPLICATIONS OF THE RESEARCH FINDINGS}

Since the students' inadequacies in mathematical thinking and problem-solving skills during national examinations have been linked to the traditional ways of assessment (Drijvers et al., 2019; Griffin et al., 2012), we felt interested in exploring and reviewing various assessment strategies that have been employed to enhance students' mathematical problem-solving abilities. It has already been stressed that enhancing students' mathematical problem-solving leads to the improved quality of mathematics teaching and learning at all levels of education (Charlesworth \& Leali, 2012). It has also been indicated that problem-solving is a mathematical competence or skill that could be enhanced by a combination of appropriate instructional and assessment strategies among other factors. Based on the findings presented in the preceding section, it has been revealed that assessment strategies such as structure of the observed learning outcomes taxonomy, higher-order thinking skills model, performance assessments, authentic assessments, dynamic assessments, and video games-based assessments alongside appropriate instructional methods like problem-based learning (PBL), cooperative learning are 
bound to enhance students' mathematical problemsolving skills.

Students with higher problem-solving capacity, are also likely to score highly in final national exams (Veerasamy et al., 2018). The results from the studies conducted by Lian et al. (2010), and Mukuka, Balimuttajjo, and Mutarutinya (2020) demonstrate a need for teachers to make use of the SOLO taxonomy, through an enhanced PBL environment, in assessing students' mathematical problem-solving abilities. This could be attributed to the fact that the SOLO taxonomy may provide teachers with insights into the instructional approaches that might have the potential to overcome students' mathematical learning difficulties. Also, it has been demonstrated that open-ended questions do not only propel logical reasoning but promotes higher-order thinking that eventually strengthens students' mathematical problem-solving skills. Pajares and Miller (1997) added that open-ended performance tests are effective in developing students' caliber and confidence in mathematics. However, teachers ought to consider students' capabilities when designing questions that demand higher-order thinking. In this sense, we agree with Lian et al. (2010) who suggested that teachers should be aware of students' problem-solving background, for the teacher to monitor students' growth in algebraic solving ability. Furthermore, the higherorder thinking skills model is designed in a way that students experience training in mathematical problemsolving skills. Within this context, students pass through the four steps including, reading carefully the given question, re-reading the question for a deep understanding of the question, making a plan and best strategy that fit to solve the problem in place, then carefully end with the calculation process (Abdullah \& Fadil, 2019). Therefore, mathematics educators need to emphasize developing students' higher-order thinking ability, develop students' self-reflection and selfregulation, apply various assessment strategies and instructions, among other aspects that are concerned with mathematical problem-solving skills development (Fan \& Zhu, 2007; Lazakidou et al., 2007).

A substantial number of the reviewed studies (7 out of 20 studies) also showed that teachers have employed performance assessments to strengthen students' mathematical problem-solving. The literature showed that after exposing students to performance assessments (PAs), students scored highly compared to those who were exposed to the non-performance assessments (Fuchs et al., 1999; Miller, 1997). Besides that, it was shown that with PAs, students developed their confidence to tackle complex mathematical problems (Novita et al., 2012). Other scholars (e.g., Mukuka, Mutarutinya, \& Balimuttajjo, 2020; Pettersen, 2017) have also stressed a need for students to showcase their competencies like communicating mathematically, mathematical reasoning, and problem-solving. It has been stressed that mathematical problem-solving tasks should trigger higher-order thinking and reasoning among learners. Teachers need to identify which competence is expected in each unit of the mathematics curriculum. In line with these expectations, teachers need to identify and categorise students' problemsolving abilities in line with the constructivist learning theory (Veerasamy et al., 2018).

The overall findings of the present study demonstrate that almost all of the assessment strategies discussed in the preceding section (research findings) could maximize students' potentials and skills in learning mathematics, if they are applied alongside active learning approaches such as problem-based learning, and cooperative learning among others. Mukuka et al. (2019) have pointed out that the ability to cooperate and work collaboratively is one of the most desired attributes for modern workplaces and classrooms. Teachers need to assess and give students tasks where they can apply mathematical knowledge to various practical situations and vice versa (see Mukuka, Balimuttajjo, and Mutarutinya, 2020), as well as performing tasks that they can freely explain (Kelly, 2006). This demonstrates a need for teachers to promote the use of assessment strategies, to strengthen students' mathematical problem-solving abilities.

It has further been demonstrated that richer assessment tasks are bound to improve students' mathematical problem-solving skills in the sense that such tasks provide intellectual challenges for conceptual understanding. A study by Downton and Sullivan (2017) in which children were interviewed using more complex multiplication tasks, revealed that exposing students to appropriate complex tasks is an alternate rich assessment strategy that has the potential to boost students' multiplicative thinking ability. The authors further attributed this to the fact that such tasks provoke students to search for more advanced strategies to solve problems. Furthermore, providing students with rich and complex tasks during class exercises and homework can boost their self-efficacy beliefs in mathematics, and understanding of the real world (Ukobizaba et al., 2019). This demonstrates that appropriate assessment of mathematical problem-solving skills can lead to the improved application of mathematical knowledge to various practical situations and the attainment of sustainable development goals (SDGs).

\section{CONCLUSION AND RECOMMENDATIONS}

Based on the arguments advanced in the discussion section, the research questions were answered in such a way that the assessment strategies that are bound to improve students' mathematical problem-solving skills have been identified. The extent to which such strategies support the development of mathematical problem- 
solving skills and their implications for future mathematics teaching practices have also been highlighted. Although the reviewed literature is not exhaustive, a substantial number of the assessment strategies that have the potential to strengthen students' mathematical problem-solving skills have been highlighted. It has also been noted that performance assessments and authentic assessments have been used in most of the reviewed studies. All the reviewed assessment strategies have been found to have a greater potential in promoting learning achievement, motivating students to tackle complex problems, and enhancing active learning for students to understand mathematics, not only in theory, but most importantly in a practical way. It is expected that, when students are assessed in a way that enhances their mathematical understanding of the concepts, then they will be able to apply the acquired skills in responding to the problems that they will encounter after schooling.

In light of this review, we make the following recommendations in responding to the future requirements of the $21^{\text {st }}$ century:

First, mathematics teachers should be encouraged to teach and assess students' mathematical knowledge and skills in a way that allows students to perform the task(s) that they undoubtedly understand. Second, mathematics teachers should not assess to only grade their students, but to get information about their students' learning progress and competencies to improve instructions. This might be achieved through the use of open-ended tasks that are likely to solicit higher-order thinking skills from students. Third, there is a serious need for more research on other forms of assessment that would help in strengthening students' mathematical problem-solving skills. With the current educational reform worldwide that places more emphasis on competency-based curriculum, teachers are encouraged to use assessment strategies (like the ones highlighted above) that will help in fostering students' logical reasoning and problem-solving skills that are relevant to modern-day society and workplaces.

Author contributions: All authors have sufficiently contributed to the study, and agreed with the results and conclusions.

Funding: No funding source is reported for this study.

Declaration of interest: No conflict of interest is declared by authors.

\section{REFERENCES}

Abdullah, A. H., \& Fadil, S. S. (2019). Emerging patterns and problems of higher-order thinking skills (HOTS) mathematical problem-solving in the Form-three assessment (PT3). South African Journal of Education, 39(2), 1-18. https:/ / doi.org/10.15700/ saje.v39n2a1552

Beesley, A. D., Clark, T. F., Dempsey, K., \& Tweed, A. (2001). Enhancing formative assessment practice and encouraging middle school mathematics engagement and persistence. School Science and Mathematics, 118(1), 4-16. https:/ / doi.org/10.1111/ ssm.12255

Berenson, S. B., \& Carter, G. S. (1995). Changing assessment practices in science and mathematics. School Science and Mathematics, 95(4), 182-186. https:// doi.org/10.1111/j.1949-8594.1995. tb15759.x

Cai, J., Moyer, J. C., \& Wang, N. (2012). Mathematical problem posing as a measure of curricular effect on students' learning. Education Studies Mathematics, 83, 57-69. https://doi.org/10.1007/s10649-0129429-3

Charlesworth, R., \& Leali, S. A. (2012). Using problem solving to assess young children's mathematics knowledge. Early Childhood Education Journal, 39(6), 373-382. https://doi.org/10.1007/s10643-0110480-y

Darma, I. K., Candiasa, I. M., Sadia, I. W., \& Dantes, N. (2018). Problem-Based Learning and Authentic Assessment on conceptual understanding and ability to solve mathematical problems (Among Students of Politeknik Negeri Bali). International Research Journal of Engineering, IT \& Scientific Research, 4(4), 7-16. https://doi.org/10.21744/ irjeis.v4n 4.254

Downton, A., \& Sullivan, P. (2017). Posing complex problems requiring multiplicative thinking prompts the use of sophisticated strategies and build mathematical connections. Educational Studies in Mathematics, 95(3), 303-328. http:/ / doi.org/10.1007/s10649-017-9751-x

Drijvers, P., Kodde-buitenhuis, H., \& Doorman, M. (2019). Assessing mathematical thinking as part of curriculum reform in the Netherlands. Educational Studies in Mathematics, 102, 435-456. https:/ / doi.org/10.1007/s10649-019-09905-7

Ebiendele, P. (2012). Critical thinking: Essence for teaching mathematics and mathematics problem solving skills. African Journal of Mathematics and Computer Science Research, 5(3), 39-43. https:// doi.org/10.5897/AJMCSR11.161

Egodawatte, G. (2010). A Rubric to self - assess and peer - assess mathematical problem solving tasks. Acta Didactica Napocensia, 3(1), 75-88.

Fan, L., \& Zhu, Y. (2007). From convergence to divergence: the development of mathematical problem solving in research, curriculum, and classroom practice in Singapore. ZDM Mathematics Education, 39, 491-501. https://doi.org/10.1007/ s11858-007-0044-1

Frank, B., Simper, N., \& Kaupp, J. (2017). Formative feedback and scaffolding for developing complex problem solving and modelling outcomes. 
European Journal of Engineering Education, 1-17. https:// doi.org/10.1080/03043797.2017.1299692

Fuchs, L. S., Compton, D. L., Fuchs, D., Hollenbeck, K. N., Craddock, C. F., \& Hamlett, C. L. (2008). Dynamic assessment of algebraic learning in predicting Third Graders' development of mathematical problem solving. Journal of Educational Psychology, 100(4), 829-850. https:// doi.org/10.1037/a0012657

Fuchs, L. S., Compton, D. L., Fuchs, D., Hollenbeck, K. N., Hamlett, C. L., \& Seethaler, P. M. (2011). Twostage screening for math problem-solving difficulty using dynamic assessment of algebraic learning. Journal of Learning Disabilities, 44(4), 372-380. https://doi.org/10.1177/0022219411407867

Fuchs, L. S., Fuchs, D., Karns, K., Hamlett, C. L., \& Katzaroff, M. (1999). Mathematics performance assessment in the classroom: Effects on teacher planning and student problem -solving. American Educational Research Journal, 36(3), 609-646. https:// doi.org/10.3102/00028312036003609

Gravemeijer, K., Stephan, M., Julie, C., Lin, F., \& Ohtani, M. (2017). What mathematics education may prepare students for the society of the future? International Journal of Science and Mathematics Education, 15(1), 105-123. https:/ / doi.org/10.1007/ s10763-017-9814-6

Griffin, P., McGaw, B., \& Care, E. (2012). Defining twenty-first century skills. In Assessment and teaching of 21st century skills. https://doi.org/ 10.1007/978-94-007-2324-5_2

Hasibuan, S. A., \& Fauzi, K. M. S. M. A. (2020). Development of PISA mathematical problem model on the content of change and relationship to measure students mathematical problem-solving ability. International Electronic Journal of Mathematics Education, 15(2), em0570. https:// doi.org/10.29333 /iejme/ 6274

Hopkins, M. H. (2000). Practicing what we preach: Authentic assessment in mathematics. Diagnostique, 25(1), 15-30. https://doi.org/10.1177/0737247799 02500104

Hwang, G. J., Hung, C. M., \& Chen, N. S. (2014). Improving learning achievements, motivations and problem-solving skills through a peer assessmentbased game development approach. Educational Technology Research and Development, 62(2), 129-145. https:// doi.org/10.1007/s11423-013-9320-7

Jang, H. (2016). Identifying 21st Century STEM competencies using workplace data. Journal of Science Education and Technology, 25(2), 284-301. https:// doi.org/10.1007/s10956-015-9593-1

Kanjee, A. (2009). Enhancing teacher assessment practices in South African schools: Evaluation of the assessment resource banks. Education as Change,
13(1), 73-89. https:/ / doi.org/10.1080/16823200902 940599

Kelly, C. A. (2006). Using manipulatives in mathematical problem solving: A performance-based analysis. The Mathematics Enthusiast, 3(2), 184-193. Retrieved from https://scholarworks.umt.edu/tme/vol3/ iss $2 / 6$

Lavrakas, P. J. (2008). Encyclopedia of survey research methods. Thousand oaks, CA: Sage Publications, Inc. https:/ / doi.org/10.4135/9781412963947

Lester, F. K. (2013). Thoughts about research on mathematical problem-solving.The Mathematics Enthousiasm, 10(1), 245-278.

Lian, L., Yew, W., \& Idris, N. (2010). Superitem test as an alternative assessment tool to assess students' algebraic solving ability. International Journal for Mathematics Teaching and Learning, 1-15. Retrieved from http://www.cimt.org.uk/journal/lian.pdf

Lin, P. (2004). Supporting teachers on designing problem-posing tasks as a tool of assessment to understand students' mathematical learning. Proceedings of the 28th Conference of the International Group for the Psychology of Mathematics Education, 2004, 3, 257-264.

Mukuka, A., Balimuttajjo, S., \& Mutarutinya, V. (2020). Applying the SOLO taxonomy in assessing and fostering students' mathematical problem-solving abilities. In P. Vale, L. Westaway, Z. Nhase \& I. Schudel (Eds.), Proceedings of the 28th Annual Conference of the Southern African Association for Research in Mathematics, Science and Technology Education (pp. 104-112). Eastern Cape, South Africa: www.saarmste.org

Mukuka, A., Mutarutinya, V., \& Balimuttajjo, S. (2019). Exploring the barriers to effective cooperative learning implementation in school mathematics classrooms. Problems of Education in the 21st Century, 77(6), 745-757. https://doi.org/10.33225/pec/ 19.77.74

Mukuka, A., Mutarutinya, V., \& Balimuttajjo, S. (2020). Data on students' mathematical reasoning test scores: A quasi-experiment. Data in Brief, 30(2020), Article 105546. https:/ / doi.org/10.1016/j.dib.2020. 105546

Nabie, M. J. (2013). Integrating problem-solving and investigations in mathematics: Ghanaian teachers' assessment practices department of mathematics education. International Journal of Humanities and Social Science, 3(15), 46-56.

Nizeyimana G., \& Muthukrishna N. (2003). Teacher perceptions of the impact of public examinations on curriculum practices: A survey in two districts of Kigalicity, Rwanda (Unpublished Dissertation), University of Natal, Pietermaritzburg, South Africa. 
Novita, R., Zulkardi, \& Hartono, Y. (2012). Exploring primary student's problem-solving ability by doing tasks like PISA's question. IndoMS. J.M.E, 3(2), 133150. https:/ / doi.org/10.22342/jme.3.2.571.133-150

Pajares, F., \& Miller, M. D. (1997). Mathematics selfefficacy and mathematical problem-solving: Implications of using different forms of assessment. The Journal of Experimental Education, 65(3), 213-228. https:/ / doi.org/10.1080/00220973.1997.9943455

Pettersen, A. (2017). Identifying competency demands in mathematical tasks: Recognising what matters. Int J of Sci and Math Educ, 1, 1-17. https://doi.org/ 10.1007/s10763-017-9807-5

Raiyn, J., \& Tilchin, O. (2016). The impact of adaptive complex cssessment on the HOT skill development of students. World Journal of Education, 6(2), 12-19. https:/ / doi.org/10.5430/wje.v6n2p12

REB. (2015). Competence -based curriculum: Summary of Curriculum Framework Pre-Primary to Upper Secondary.

Rosli, R., Goldsby, D., \& Capraro, M. M. (2013). Assessing students' mathematical problem-solving and problem-posing skills. Asian Social Science, 9(16), 54-60. https://doi.org/10.5539/ass.v9n16 p54

Schoen, R. C., Lavenia, M., Ozsoy, G., Schoen, R. C., Lavenia, M., \& Ozsoy, G. (2019). Teacher beliefs about mathematics teaching and learning: Identifying and clarifying three constructs. Cogent Education, 6(1), 1-29. https://doi.org/10.1080/ 2331186X.2019.1599488

Scott, C. L. (2015). The futures of learning 3: What kind of pedagogies for the 21st century? Education Research and Foresight, 15, 1-21.
Stacey, K. (2005). The place of problem solving in contemporary mathematics curriculum documents. Journal of Mathematical Behavior, 24, 341350. https:/ / doi.org/10.1016/j.jmathb.2005.09.004

Suto, I. (2013). 21st Century skills: Ancient, ubiquitous, enigmatic? Research Matters, 15, 2-8.

Taras, M. (2008). Summative and formative assessment: Perceptions and realities. Active Learning in Higher Education, 9(2), 172-192. https://doi.org/10.1177/ 1469787408091655

Ukobizaba, F., Ndihokubwayo, K., Mukuka, A., \& Uwamahoro, J. (2019). Insights of teachers and students on mathematics teaching and learning in selected Rwandan secondary schools. African Journal of Educational Studies in Mathematics and Sciences, 15(2), 93-107. https://doi.org/10.4314/ ajesms.v15ii2.8

Veerasamy, A. K., Souza, D. D., \& Lindén, R. (2018). Relationship between perceived problem solving skills and academic performance of novice learners in introductory programming courses. Journal of Computer Assisted Learning, 35(2), 1-10. https://doi.org/10.1111/jcal.12326

Wang, T. H. (2011). Implementation of Web-based dynamic assessment in facilitating junior high school students to learn mathematics. Computers and Education, 56(4), 1062-1071. https:/ / doi.org/10.1016/j.compedu.2010.09.014

Wilson, J. W., Fernandez, M. L., \& Nelda, H. (1993). Research ideas for the classroom: High school mathematics. New York: MacMillan. 


\section{APPENDIX}

\section{The Contribution of Assessment Strategies in Enhancing Mathematical Problem Solving Skills}

\begin{tabular}{|c|c|c|c|c|}
\hline$\overline{\mathrm{SN}}$ & Author(s) and date & Title (Assessment strategies employed) & Sample size & Approaches \\
\hline 1 & $\begin{array}{l}\text { Abdullah and } \\
\text { Fadil (2019) }\end{array}$ & $\begin{array}{l}\text { Emerging patterns and problems of higher-order } \\
\text { thinking skills (HOTS) mathematical problem-solving in } \\
\text { the Form-three assessment (PT3) }\end{array}$ & 10 Form-3 students & $\begin{array}{l}\text { Oral reporting (i.e. thinking aloud } \\
\text { protocol) }\end{array}$ \\
\hline 2 & Beesley et al. (2001) & $\begin{array}{l}\text { Enhancing Formative Assessment Practices and } \\
\text { Encouraging Middle School Mathematics Engagement } \\
\text { and Persistence }\end{array}$ & $\begin{array}{l}47 \text { mathematics } \\
\text { teachers }\end{array}$ & Schools received PD \\
\hline 4 & Darma et al. (2018) & $\begin{array}{l}\text { Problem-Based Learning and Authentic Assessment on } \\
\text { Conceptual Understanding and Ability to Solve } \\
\text { Mathematical Problems (Among Students of Politeknik } \\
\text { Negeri Bali) }\end{array}$ & 110 students. & $\begin{array}{l}\text { Comprehension test, and the } \\
\text { problem-solving test }\end{array}$ \\
\hline 5 & Egodawatte (2010) & $\begin{array}{l}\text { Rubric to Self - Assess and Peer - assess Mathematical } \\
\text { Problem Solving Tasks. }\end{array}$ & - & Attitude questionnaire \\
\hline$\overline{6}$ & Frank et al. (2017) & $\begin{array}{l}\text { Formative feedback and scaffolding for developing } \\
\text { complex problem solving and modeling outcomes }\end{array}$ & - & $\begin{array}{l}\text { Scaffolded tasks in-class, formative } \\
\text { assignments, and post-assignment } \\
\text { review }\end{array}$ \\
\hline$\overline{7}$ & Fuchs et al. (1999) & $\begin{array}{l}\text { Mathematics Performance Assessment in the Classroom: } \\
\text { Effects on Teacher Planning and Student Problem } \\
\text { Solving }\end{array}$ & 16 teachers & $\begin{array}{l}\text { Use of Performance Assessment } \\
\text { (PA) or no-PA }\end{array}$ \\
\hline 8 & Fuchs et al. (2008) & $\begin{array}{l}\text { Dynamic Assessment of Algebraic Learning in Predicting } \\
\text { Third Graders' Development of Mathematical Problem } \\
\text { Solving }\end{array}$ & $\begin{array}{l}122 \text { third-grade } \\
\text { students }\end{array}$ & Word-problem assessment \\
\hline 9 & Fuchs et al. (2011) & $\begin{array}{l}\text { Two-stage screening for math problem-solving difficulty } \\
\text { using dynamic assessment of algebraic learning. }\end{array}$ & $\begin{array}{l}122 \text { third-grade } \\
\text { students }\end{array}$ & $\begin{array}{l}\text { A test of math word-problem skill } \\
\text { and DA of algebraic learning }\end{array}$ \\
\hline 10 & $\begin{array}{l}\text { Hasibuan and } \\
\text { Fauzi (2020) }\end{array}$ & $\begin{array}{l}\text { Development of PISA Mathematical Problem Model on } \\
\text { the Content of Change and Relationship to Measure } \\
\text { Students Mathematical Problem-Solving Ability }\end{array}$ & $\begin{array}{l}32 \text { students of Grade } \\
\text { VIII }\end{array}$ & $\begin{array}{l}\text { Walkthrough, documents, tests, and } \\
\text { questionnaires }\end{array}$ \\
\hline 12 & Lian et al. (2010) & $\begin{array}{l}\text { Superitem Test as an Alternative Assessment Tool to } \\
\text { Assess Students' Algebraic Solving Ability. }\end{array}$ & $\begin{array}{l}\text { Nine Form Four } \\
\text { students }\end{array}$ & An interview assessment \\
\hline$\overline{13}$ & Lin (2004) & $\begin{array}{l}\text { Supporting teachers on Designing Problem solving tasks } \\
\text { as a Tool of Assessment to Understand Students' } \\
\text { Mathematical Learning }\end{array}$ & - & Assessment integral to instruction \\
\hline$\overline{14}$ & $\begin{array}{l}\text { Mukuka, } \\
\text { Balimuttajjo, and } \\
\text { Mutarutinya (2020) }\end{array}$ & $\begin{array}{l}\text { Applying the SOLO taxonomy in assessing and fostering } \\
\text { students' mathematical problem-solving abilities }\end{array}$ & 80 Grade 11 students & Pre-posttest \\
\hline 15 & Nabie (2013) & $\begin{array}{l}\text { Integrating Problem Solving and Investigations in } \\
\text { Mathematics: Ghanaian Teachers' Assessment Practices. }\end{array}$ & $\begin{array}{l}159 \text { certificated } \\
\text { teachers }\end{array}$ & $\begin{array}{l}\text { A questionnaire consisting of both } \\
\text { closed-ended and open-ended items }\end{array}$ \\
\hline$\overline{16}$ & Novita et al. (2012) & $\begin{array}{l}\text { Exploring Primary Student's Problem-Solving Ability by } \\
\text { Doing Tasks Like PISA's Question }\end{array}$ & $\begin{array}{l}188 \text { Palembang } \\
\text { (students) }\end{array}$ & Formative evaluation type \\
\hline 17 & $\begin{array}{l}\text { Pajares and Miller } \\
(1997)\end{array}$ & $\begin{array}{l}\text { Mathematics Self- Efficacy and Mathematical Problem } \\
\text { Solving: Implications of Using Different Forms of } \\
\text { Assessment }\end{array}$ & $\begin{array}{l}327 \text { eighth-grader } \\
\text { students }\end{array}$ & $\begin{array}{l}\text { Two forms of assessment (traditional } \\
\text { multiple-choice vs. open-ended fill- } \\
\text { in-the-blank }\end{array}$ \\
\hline 18 & $\begin{array}{l}\text { Raiyn and Tilchin } \\
\text { (2016) }\end{array}$ & $\begin{array}{l}\text { The Impact of Adaptive Complex Assessment on the } \\
\text { HOT Skill Development of Students }\end{array}$ & - & $\begin{array}{l}\text { Personalized and collaborative } \\
\text { problem-based learning (PBL) }\end{array}$ \\
\hline 19 & Rosli et al. (2013) & $\begin{array}{l}\text { Assessing Students' Mathematical Problem-Solving and } \\
\text { Problem-Posing }\end{array}$ & - & - \\
\hline 20 & Wang (2011) & $\begin{array}{l}\text { Implementation of Web-based dynamic assessment in } \\
\text { facilitating junior high school students to learn } \\
\text { mathematics. }\end{array}$ & $\begin{array}{l}96 \text { junior high school } \\
\text { seventh-graders } \\
\text { (students) }\end{array}$ & $\begin{array}{l}\text { GPAM-WATA, normal Web-based } \\
\text { test (N-WBT), and paper-and-pencil } \\
\text { test (PPT) }\end{array}$ \\
\hline
\end{tabular}

\section{http://www.ejmste.com}

